\title{
Uzamış febril myalji sendromu ile başvuran ailesel akdeniz ateşi: 9 hastanın klinik, laboratuvar ve demografik özellikleri
}

\section{Familial mediterranean fever with prolonged febrile myalgias syndrome: Clinical, laboratory and demographic characteristics of 9 patients}

\author{
(1) Alaaddin Yorulmaz, ${ }^{1}$ (1) Hikmet Akbulut, ${ }^{1}$ (i) Şükrü Arslan² \\ 'Selçuk Üniversitesi Tıp Fakültesi, Çocuk Sağlığı ve Hastalıkları Anabilim Dalı, Konya, Turkey \\ ${ }^{2}$ Selçuk Üniversitesi Tıp Fakültesi, Çocuk Romatoloji Bilim Dalı, Konya, Turkey
}

\section{Özet}

Amaç: Bu çalışmanın amacı Ailevi Akdeniz Ateş'li hastalarda uzamış febril myalji sendromlu bir grup hastayı geriye dönük olarak incelemek ve klinik tecrübemizi paylaşmaktır.

Gereç ve Yöntem: UFMS'li dokuz hasta Selçuk Üniversitesi Tıp Fakültesi Pediatri Acil Servisi ve Pediatrik Romatoloji Polikliniği (Eylül 2016- Mayıs 2018) elektronik veri tabanından tanımlandı. Klinik ve laboratuvar verileri toplandı. Hastaların yaşı, cinsiyet, eşlik ettiği semptomlar, Ailevi Akdeniz Ateş'in eski tanı ise takip süresi, tanı konulduktan sonraki takip süresi, hastanede yatış süresi, semptomların kaç gün öncesinden başladığı, tam kan sayımı, akut faz reaktanları gibi veriler kaydedildi.

Bulgular: Çalışmada 9 hastanın 7'si (\%77.8) kadın, 2'si (\%22.2) erkekti. Hastalarımızın yaşları 39 ay ile 192 ay arasında değişmekte olup median ortalaması 145 ay idi. Hastaların sadece 2'sine $(\% 22,2)$ daha önce tanı konulmuş olup kolşisin tedavisi almaktaydı. Hastaların 7'sinde $(\% 77,78)$ Ailevi Akdeniz Ateş'inin ilk belirtisi Uzamış Febril Myalji Sendromudur. Hastaların genetik analizine bakıldığında 4 hastada $(\% 44,44)$ M694V homozigot tespit edildi. Tüm hastalarda akut faz reaktanları yüksek seviyede idi. Kreatin kinaz düzeyi tüm hastalarda normal sınırlardaydı. Pulse kortikosteroid tedavisi, 10 mg / kg dozunda uygulandı. Tüm hastalarda tedavi sonrası tam iyileşme görüldü.

Sonuç: Ailevi Akdeniz Ateşi kriterlerini karşılamayan, yüksek ateşle birlikte akut faz reaktanı yüksekliğinin olduğu ve uzun süren myalji varlığında Uzamış Febril Myalji Sendromu düşünülmelidir.

Anahtar Sözcükler: Ailesel Akdeniz ateşi; çocuk; uzamış febril myalji.

\begin{abstract}
Introduction: The aim of this study is to retrospectively review a group of patients with prolonged febrile myalgias syndrome in patients with familial mediterranean fever and to share their clinical experience.

Methods: Nine patients with prolonged febrile myalgias syndrome were identified from the electronic database of a Selçuk University Medical Faculty Pediatric Emergency Department and Pediatric Rheumatology Polyclinic (September 2016-May 2018). Their clinical and laboratory data were collected. Data such as age, sex, accompanying symptoms of familial mediterranean fever, previous follow-up of familial mediterranean fever, duration of follow-up after diagnosis, hospital stay, number of days before symptoms, complete blood count and acute phase reactants were recorded. Pulse corticosteroid therapy was administered at a dose of $10 \mathrm{mg} / \mathrm{kg}$.

Results: In the study, 7 of 9 patients (77.8\%) were females and 2 (22.2\%) were male. The ages of our patients ranged from 39 months to 192 months and the mean median was 145 months. Only 2 (22.2\%) of the patients had previously been diagnosed and received colchicine treatment. The first sign of familial mediterranean fever in 7 of patients (77.78\%) was prolonged febrile myalgia syndrome. When genetic analysis of the patients was examined, M694V homozygous was detected in 4 patients (44.44\%). Acute phase reactors were at high level in all patients. Creatine kinase levels were within normal limits in all patients. The patients received intravenous methylprednisolone. In all patients, complete recovery was seen after treatment.

Discussion and Conclusion: Prolonged Febrile Myalgia Syndrome should be considered in the presence of high fever, acute phase reactant height, and long-standing myalgia that does not meet familial mediterranean fever criteria.

Keywords: Familial Mediterranean fever; child; protracted febrile myalgia.
\end{abstract}

Corresponding (illetişim): Alaaddin Yorulmaz, Selçuk Üniversitesi Tıp Fakültesi, Çocuk Sağlığı ve Hastalıkları Kliniği, Konya, Turkey E-mail (E-posta): dralaaddiny@gmail.com 
A lesel Akdeniz Ateşi (AAA), ateş ve steril poliserözit atakları ile karakterize otozomal resesif geçişli sistemik bir otoinflamatuar hastalıktır. Hastalığın klasik klinik tablosunu tekrarlayan ateş, karın ağrısı atakları ve eklem bulguları, nadiren de göğüs ağrısı ve ciltte erizipel benzeri döküntü oluşturur ve hastalar genellikle ataklar arasında asemptomatiktir. ${ }^{[1-3]} \mathrm{Ge}-$ nellikle Akdeniz bölgesinde, çoğunlukla Yahudi, Türk, Arap ve Ermeni soylarını etkilemektedir. ${ }^{[4]}$ Hastalığın ülkemizdeki tahmini sıklığı 1/1,000, taşıyıcı oranı ise 1:5 olarak bildirilmektedir. [5,6] AAA'nin sorumlu geni ilk kez 1992'de tanımlanan ve daha sonra yaklaşık olarak 30 mutasyon saptanan MEFV genidir. ${ }^{[7]}$ En yaygın olanları M694V ve V726A'dır. Değişken MEFV mutasyonları farklı tanı, tedavi ve prognostik sonuçlara sahiptir. ${ }^{[8]}$

Hastalığın seyri sırasında belirgin olarak artmış sıklıkta vaskülitlere rastlandığı bildirilmiştir. ${ }^{[9,10]}$ En sık görülen vaskülitik sendromlar Henoch Schönlein purpurası (HSP) ve poliarteritis nodozadır (PAN). AAA'daki bir diğer vaskülit tablosu da uzamış febril myalji sendromudur (UFMS). İlk kez 1994 yılında Langevitz tarafından tanımlanmış olan bu sendrom, yüksek ateş, karın ağrısı, ishal, artrit/artralji geçici vaskülitik döküntü ve şiddetli-ağır paralize edici myalji ile karakterizedir. ${ }^{[7]}$ Yüksek eritrosit sedimentasyon hızı (ESR), hipergammaglobulinemi, normal kreatinin fosfokinaz (CPK) ve lökositoz diğer bulgularıdır. ${ }^{[11]}$ Elektromyografideki (EMG) nonspesifik inflamatuar myopatik değişiklikler görülmektedir. ${ }^{[1]}$ UFMS'un epizodu, kortikosteroidlerle tedavi edilmezse $4-6$ hafta sürer. ${ }^{[11]}$ Kolşisin profilaksi tedavisi altında bile tekrarlayabilir.

Bu çalışmanın amacı AAA'li hastalarda uzamış febril myalji sendromlu bir grup hastayı geriye dönük olarak incelemek ve klinik tecrübemizi paylaşmaktır. UFMS'nun tanısını kolaylaştırmak ve akılda tutulmasını sağlamak amacıyla sendromun klinik ve laboratuvar bulgularını, genetik mutasyonları ve tedavi seçeneklerini inceledik.

\section{Gereç ve Yöntem}

01 Eylül 2016-01 Mayıs 2018 tarihleri arasında Selçuk Üniversitesi Tıp Fakültesi Çocuk Acil servisi ve Çocuk Romatoloji polikliniğine başvuran Uzamış Febril Myali tanısı konulmuş olan
9 çocuk hasta çalışmaya alındı. Hastaların hastane otomasyon sistemine girilen kayıtları ve dosyaları etik kurul onayı alındıktan sonra geriye dönük olarak incelendi. Yaş, cinsiyet, eşlik ettiği semptomlar, AAA'un eski tanı ise takip süresi, tanı konulduktan sonraki takip süresi, hastanede yatış süresi, semptomların kaç gün öncesinden başladığı, tam kan sayımı, akut faz reaktanları gibi veriler elde edildi.

Artrit ve uzamış ateşi olan hastalar, travma ve enjeksiyona maruz kalmış hastalar, sistemik hastalık öyküsü ve ailede kas hastalığı öyküsü olan hastalar çalışmaya alınmadı.

UFMS tanısı daha önce önerilen kriterlerde yer alan yüksek ateş, yüksek akut faz reaktanları seviyesi, en az bir M694V tanımlanması ve en az 5 gün süren şiddetli myalji varlığında konuldu. ${ }^{[12]}$

Tüm hastalarda tam fizik muayene yapıldı. İlk değerlendirmede acil olarak, hemogram, serum CPK, aspartat aminotransferaz (AST), alanin aminotransferaz (ALT), laktat dehidrogenaz $(\mathrm{LDH})$, tam idrar analizi, C-reaktif protein (CRP), ESR, böbrek fonksiyon testleri istendi. Tüm hastalar genetik olarak en yaygın MEFV mutasyonları için (M694V, M694I, M680I, K695R, R761H, A744S, P369S, V726A ve E148Q) Sanger dizilemesi ile genetik olarak test edildi.

Çalışmada elde edilen veriler, istatistiksel analizleri için SPSS 21.0 (SPSS Inc, Chicago, Illinois, United States of America) paket bilgisayar programı kullanıldı. Verilerin normal dağılıma uygun olup olmadığını ortaya koymak amacıyla Kolmogorow-Smirnov ve Shapiro-Wilk normallik testleri yapıldı. Kategorik değişkenler sayı (n) ve yüzde (\%) olarak, kantitatif veriler Mean士SD, medyan, range (minimum-maksimum) olarak gösterildi.

\section{Bulgular}

Çalışmaya alınan 9 hastanın 7'si $(\% 77,8)$ kız, 2'si $(\% 22,2)$ erkek idi. Hastaların demografik, klinik ve genetik özellikleri Tablo 1 'de gösterilmiştir. Hastalarımızın yaşları 39 ay ile 192 ay arasında değişmekte olup median ortalaması 145 ay idi. Hastaların sadece 2'sine $(\% 22,22)$ daha önce tanı konulmuş olup kolşisin tedavisi almaktaydı. 7'sinin ise $(\% 77,78)$ AAA'inin ilk belirtisi UFMS idi. Hastaların genetik analizine bakıldığında 4 hastada

Tablo 1. Uzamış febril myaljili hastaların demografik, klinik ve genetik özellikleri

\begin{tabular}{|c|c|c|c|c|c|c|c|c|c|c|}
\hline Hasta no & Yaş (ay) & Cinsiyet & Gen mutasyonu & Miyalji & Ateş & Artralji & Artrit & Aft & ÜSYE & Karın ağrısı \\
\hline 1 & 121 & $\mathrm{E}$ & M694V/M680I & + & + & + & + & - & - & + \\
\hline 2 & 151 & $\mathrm{~K}$ & M694V/M694V & + & + & + & - & - & - & + \\
\hline 3 & 152 & $\mathrm{~K}$ & M694V/M694V & + & + & - & + & - & + & - \\
\hline 4 & 132 & $\mathrm{~K}$ & M694V/M680I & + & + & + & - & + & + & + \\
\hline 5 & 39 & $\mathrm{~K}$ & M694V/M680I & + & + & - & + & - & + & - \\
\hline 6 & 165 & $\mathrm{~K}$ & M694V/M694V & + & + & + & - & - & + & + \\
\hline 7 & 192 & $\mathrm{E}$ & M694V/V726A & + & - & + & + & - & - & + \\
\hline 8 & 105 & $\mathrm{~K}$ & M694V/E148Q & + & - & + & + & - & - & + \\
\hline 9 & 145 & K & M694V/M694V & + & + & - & - & + & + & + \\
\hline
\end{tabular}


Tablo 2. Uzamış febril myaljili hastaların klinik ve laboratuar özellikleri

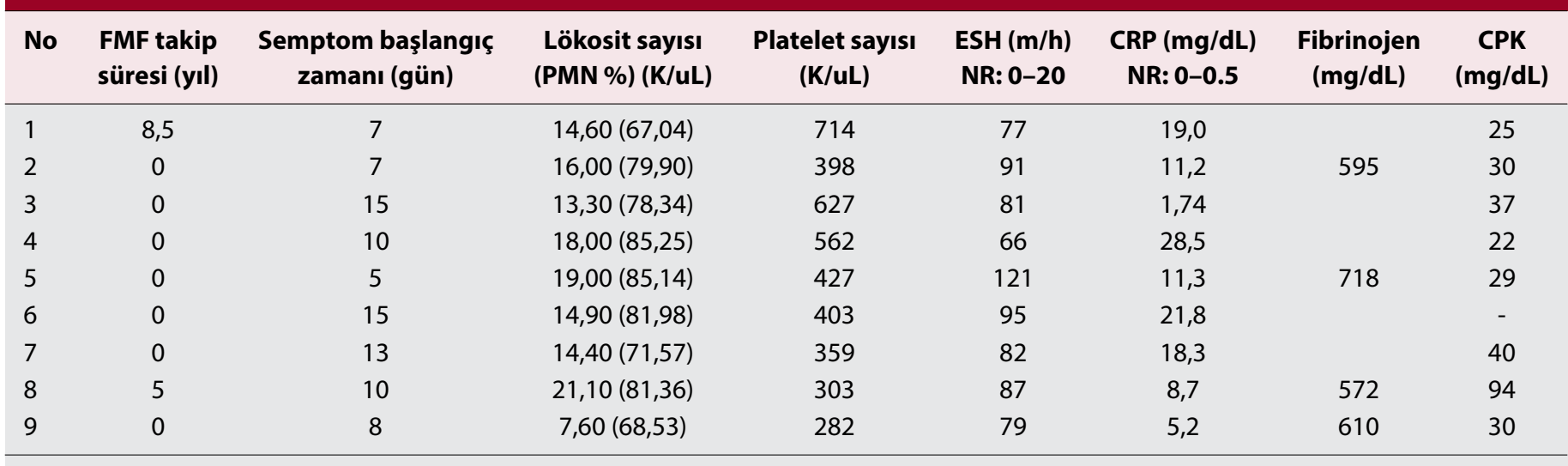

PMN: Polimorfonükleer nötrofil; ESH: Eritrosit sedimantasyon hızı; CRP: C-reaktif protein; CPK: Kreatin fosfokinaz; NR: Normal range.

Tablo 3. Uzamış febril myaljili hastaların hastanede yatış sırasındaki klinik parametreler ve taburculukta laboratuvar parametreleri

\begin{tabular}{|c|c|c|c|c|c|}
\hline No & $\begin{array}{c}\text { Pulse steroid verilme } \\
\text { süresi (gün) }\end{array}$ & $\begin{array}{l}\text { Yatış süresi } \\
\text { (gün) }\end{array}$ & $\begin{array}{l}\text { Lökosit sayısı } \\
\text { (PMN \%) (K/uL) }\end{array}$ & $\begin{array}{c}\text { ESH } \\
(\mathrm{m} / \mathrm{h}) \mathrm{NR}: 0-20\end{array}$ & $\begin{array}{c}\text { CRP } \\
\text { (mg/dL) NR: 0-0.5 }\end{array}$ \\
\hline 1 & 6 & 7 & $6,80(46,91)$ & 4 & 0,18 \\
\hline 2 & 3 & 4 & $17,00(53,24)$ & 8 & 0,22 \\
\hline 3 & 3 & 4 & $15,90(70,56)$ & 32 & 0,10 \\
\hline 4 & 4 & 5 & $8,50(60,27)$ & 22 & 2,63 \\
\hline 5 & 4 & 5 & $7,10(67,52)$ & - & - \\
\hline 6 & 4 & 6 & $12,30(77,22)$ & 22 & 3,30 \\
\hline 7 & 3 & 4 & $6,30(72,94)$ & - & - \\
\hline 8 & 6 & 11 & $8,20(75,96)$ & 2 & 1,72 \\
\hline 9 & 4 & 5 & $7,20(76,31)$ & 12 & 1,24 \\
\hline
\end{tabular}

ESH: Eritrosit sedimantasyon hızl; CRP: C-reaktif protein.

$(\% 44,44)$ M694V homozigot tespit edildi. Diğer hastaların tamamında en az bir allelinde M694V mutasyonu mevcuttu.

Sendromun ayırt edici özelliği olan myalji, hastaların \%100'ünde ortaya çıktı ve 7'sinde bilateraldi. Bu hastaların tamamında alt ekstremite etkilenmişti. Ayrıca 4 hastada da üst ekstremite tutulmuştu. Hastaların 7 'sinde $(\% 77,78)$ hastaneye başvuru esnasında ateş mevcuttu (Tablo 1). Karın ağrısı 7 hastada $(\% 77,78)$, artralji veya artrit 6 hastada $(\% 66,67)$ görüldü. Semptomların başlama zamanı ile tanı konulması arasındaki geçen ortalama süre 10 $\pm 3,6$ gün (5-15 gün) idi.

Tüm hastalarda akut faz reaktanları yüksek seviyede idi. Uzamış Febril Myaljili hastaların klinik ve laboratuar özellikleri Tablo 2'de gösterilmiştir. Ortalama Eritrosit sedimantasyon hızı $86,55 \pm 15,41 \mathrm{~mm} / \mathrm{h}$ (range: 66-121) idi. Ortalama CRP seviyesi $13,96 \pm 8,55 \mathrm{mg} / \mathrm{dL}$ (range: $1,74-28,50)$ idi. 8 hastada $(\% 88,89)$ CRP düzeyi 10 kat üzerinde $\operatorname{artış~(~}>5 \mathrm{mg} / \mathrm{dL}$ ) görüldü. 4 hastada bakılan fibrinojen düzeyi yüksek tespit edildi. Ortalama

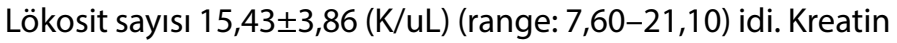
kinaz (CK) düzeyi tüm hastalarda normal sınırlardaydı.

Uzamış Febril Myaljili hastaların hastanede yatış sırasındaki klinik parametreler ve taburcu edilmeden önceki laboratuvar parametreleri Tablo 3'te gösterilmiştir. Hastalara tedavide, 10 $\mathrm{mg} / \mathrm{kg}$ metilprednisolon intravenöz uygulandı. Ortalama pul-

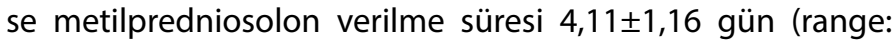
3-6) idi. Tüm hastalarda tedavi sonrası tam iyileşme görüldü. Hiçbir hasta nonsteroid antiınflamatuar ilaçlar (NSAii) başlanmadı. 4 hasta hastaneye başvurmadan önce NSAil kullanmış olup fayda görmemişti. Tüm hastalar oral prednizon 4-6 hafta kadar kullanacak şekilde tedavileri düzenlenerek taburcu

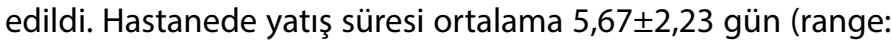
4-11 gün) idi. Tüm hastaların 1 ay sonra kontrole geldiklerinde herhangi şikayetleri yoktu.

\section{Tartışma}

Eklem ve kas ağrıları çocukluk çağında polikliniğe başvuru sebepleri arasında sıklıkla gözlenmektedir. Özellikle ağrıların uzun süreli olması ve çocuğun günlük aktivitesini bozacak şekilde yaşam kalitesini engellemesi ebeveynlerin bu konuda sıkıntı yaşamasına sebep olmaktadır. Okul çağı çocuklarının \%15'i tekrarlayan ekstremite ağrılarıyla başvururken; yaklaşık 


\section{\%5'inde bu ağrı üç aydan uzun sürer. ${ }^{[13]}$}

Çocukluk çağında görülen eklem ve kas ağrılarına sebep olan hastalıklar ayrıntılı değerlendirilmelidir. Bu şikâyetler birçok hastalığa eşlik edebileceğinden detaylı bir anamnez ve fizik muayene ile ağrının yanında başka bir bulgunun olup olmadığı incelenmelidir. Hızlı ve doğru tanı için dikkatli bir öykü almak, fizik muayene yapmak, hekime birçok ipucu sağlamaktadır. ${ }^{[14]}$ Eklem ve kas ağrısı olan çocuklarda özellikle artrit varlığı durumun daha acil ve dikkatli değerlendirilmesi gerektiğini göstermektedir.

Farklı klinik bulgularla da ortaya çıkabilen AAA; tekrarlayan ateş ve serozit atakları ile karakterize kendini sınılayan sistemik otoenflamatuar bir hastalıktır. ${ }^{[3]}$ Karın ağrısı ve $6-72$ saat arasında süren 38 derece üzeri ateş atakları ile karakterizedir. ${ }^{[15]}$ Özellikle doğu Akdeniz havzasında yaşayan ırklarda artmış sıklıkta görülmektedir. Illk AAA atağı hastaların \%75'inde yaşamın ilk 10 yılı içerisinde görülür. Atağın süresi 2-4 gün arasında olmasına rağmen daha uzun ya da daha kısa süren nöbet şekilleri de olabilir. Aile hikayesi etnik köken ve klasik klinik bulgular varlığında tanı koymak kolaydır. Tanıda esas olan klinik kriterlerdir. ${ }^{[2,3,16]}$ Ancak, tipik klinik bulguların olmadığı hastalarda tanı zorlukları sık olarak yaşanmaktadır. 1997 yılında MEFV geninin bulunmasıyla şüpheli olgularda mutasyon analizi yardımcı tanı yöntemi olarak kullanılmaktadır.

AAA'nın 16. kromozomun kısa kolundaki MEFV genindeki mutasyonlar sonucu oluştuğu bilinse de mutasyon olması hastalığın kesin tanısını koydurmaz. Çünkü bazı hasta çocuklarda gen mutasyonları saptanmazken bazı sağlıklı çocuklarda homozigot ya da heterozigot olarak her iki mutasyon da görülebilmektedir. Bu durum AAA tanısı için gen mutasyonlarının her zaman yol gösterici olmadığının ve klinik gözlemin tanı için esas olduğunun kanıtıdır. ${ }^{[17]}$ Günümüzde üç yüz seksenin üzerinde mutasyon belirlenmiş olsa da birçok merkezde en sık görülen mutasyonlar bakılmaktadır. Bunların arasından M694V mutasyonunun hastalık başlangıç yaşının erken olmasıyla, amiloidozla, artrit ve plörezi sıklığıyla daha yakın ilişkili olduğu belirtilmektedir. ${ }^{[2]}$ Ayrıca M694V mutasyonunun uzamış febril miyalji tanısı konulan hastalarda sıklıkla görülmesi bu hastalıkla da ilişkili olabileceğini düşündürmektedir. ${ }^{[18]}$

Uzamış febril miyalji; ateş yüksekliği ve paraliziye neden olabilecek kadar ağır ve şiddetli miyalji ile karakterize, bazen de karın ağrısı, artrit ve döküntülerin eşlik edebileceği $A A A^{\prime} n ı n$ nadir rastlanan bir komplikasyonudur. Çalışmalarda, AAA olgularının \%1,2'sinde birlikte görüldüğü belirlenmiştir. ${ }^{[11,19,20]}$ Hastalarda görülen bu şiddetli durumun ayırıcı tanısında infeksiyöz, malign ve romatolojik hastalıklar düşünülmelidir. Kuvvet kaybı, kas ağrısı ve buna eşlik eden ateş yüksekliği, karın ağrısı görülmektedir. Hastalık varlığında CRP, eritrosit sedimantasyon hızı ve lökosit sayısı yüksek bulunurken kreatin fosfokinaz seviyeleri her zaman düşük olarak saptanmaktadır.

FMF'nin bulguları ile ilişkili olarak myalji ilk olarak iki Ermeni'de Schwabe tarafından tanımlanmıştır. ${ }^{[2]}$ Daha sonra Majeed ve ark. AAA'lı 264 çocukta prospektif olarak myaljinin insidansını ve klinik paternlerini araştırmış ve insidansını \%25 olarak bulmuşlardır. ${ }^{[7]}$ AAA myalji üç gruba ayrılmaktadır: 1- Spontan myalji: Egzersiz ile ilgili olmayan hafif veya orta myalji 2- Egzersize bağlı myalgia: 1-3 gün süren egzersizden sonra 8 saat içinde şiddetli myalji görülmektedir. Çoğu kez istirahatla düzelir ve nadiren nonsteroid antiinflamatuar ilaç kullanımı gerektirir. 3- Tüm myalji vakalarının \%11'ini oluşturan UFMS'dur. ${ }^{[7,22]}$ UFMS şiddetli kas ağrısı ve kas güçsüzlüğü şeklinde olup genellikle bilateraldir ve alt ekstremitelerde görülür. Bazı hastalarda ise tüm kaslar tutulabilir. ${ }^{[23]}$ Kas ağrılarına yüksek ateş eşlik edebilir ve tedavi edilmezse 6 haftaya kadar uzayabilmektedir. ${ }^{[1]}$ Hastalarımızın tamamında myalji alt ekstremitelerde olup bilateral tutulum göstermekteydi.

Uzamış febril myalji sendromu, AAA ilk tanı anında veya kolşisin tedavisi ile izlem sırasında görülebilmektedir. ${ }^{[7,12,24-26]}$ iki hastamızda kolşisin tedavisi kullanırken tanı konuldu. Son zamanlardaki çalışmalarda, UFMS'nin özellikle M694V heterozigot ve homozigot mutasyonlarla ilişkili olduğunu gösterilmiştir. ${ }^{[18,27-29]}$ Olgularımızın dördünde homozigot M694V mutasyon ve diğerlerinde ise heterozigot M694V mutasyonu saptadık. Serimizde homozigot yaygınlı oranı yüksekti. M694V mutasyonu ve UFMS arasında güçlü bir bağlantı vardır, ancak ikisinin arasındaki biyokimyasal mekanizma hala belirsizdir.

Yapılan çalışmalarda yüksek düzeyde ESR ve CRP düzeylerinin UFMS'nun tanısal değerini vurgulamaktadırlar. ${ }^{[12]}$ Serimizde yer alan tüm hastalarda yüksek ESR, CRP, WBC, trombosit sayısı ve fibrinojen düzeyine sahipti. Enflamasyon iki belirleyicisi olan ESR ve CRP yüksek oranda artmıştır. Hastaların $\% 66,67$ 'sinde ESR düzeyi $>80 \mathrm{~mm} / \mathrm{saat}$ olarak belirlendi. Hastaların $\% 88,89$ 'unda CRP düzeyi normalden 10 kat daha yüksek (CRP $>5 \mathrm{mg} / \mathrm{dL}$ ) bulundu.

Semptomların başlamasından tanıya kadar geçen ortalama süre ortalama 10 gün olması nispeten uzun bir gecikme kabul edilmektedir. Bu da UFM sendromunun klinisyenler açısından farkındalığının eksik olduğunu vurgulamaktadır.

Myalji ve ateş nedeni olarak AAA'lı her hastada poliarteritis nodosa olasılığı göz önüne alınmalıdır. Bununla birlikte, hiçbir hastamız çocukluktaki PAN için sınıflandırma kriterlerini karşılamamıştır ve tedavinin sona ermesinden sonra nüks görülmemiştir.

Hastalarımızda UFMS tanısı klinik belirtilere, yüksek akut faz reaktanlarının varlığına, normal CPK ve geçmiş tıbbi öyküye göre konuldu. Son zamanlarda, Kaplan ve ark. 2007 yılında çok merkezli bir kohort çalışmasında UFMS'lu hastaları analiz ederek uzamış febril myalji tanısı için klinik ve laboratuar özelliklerini içeren bir takım kriterler oluşturulmuştur. ${ }^{[12]}$ Bunlar, üç zorunlu (ailesel FMF öyküsü veya FMF kliniği, myalji ve 5 günden uzun süren myalji kalıcılı̆ı) ve üç destekleyici (en az bir M694V mutasyonunun varlığı, yüksek inflamatuar marker düzeyi, ateş >38) kriterden oluşmaktadır. Bu kriterler ateşi içermesine rağmen, serilerde tanımlanan hastaların \%29'u ateşsizdir. Ancak bu çalışmalar kısıtlı sayıda vakalar üzerinden geliştirilmiş̧ir. Yine de serimizdeki vakaların tanısal değeri bu kriterleri karşılamaktadır. Olgularımızın \%22,2'si ateşsiz idi.

UFMS'unun etiyopatogenezi açık değildir. AAA ile ilişkili vaskü- 
litte immün mekanizmalar rol oynamaktadır. ${ }^{[9,30]}$ Tekin ve ark. AAA'lı iki hastada cilt biyopsi örneklerinin immünofloresan mikroskopisinde perivasküler lgM ve C3'ün pozitif olduğunu göstermiştir. ${ }^{[9]}$ Yine Duru ve ark. nın yaptıkları çalışmalarında iki hastanın deri biyopsisinde lgA, C3 ve fibrinojen varlığını tespit etmişlerdir. ${ }^{[31]}$ Dolaşımdaki immün komplekslerin oluşumu, kompleman tüketimi ve FMF atağı sırasında tümör nekroz faktörünün kontrolsüz salınımı, AAA hastalarında tanımlanmıştır. $\mathrm{Bu}$ nedenle, immün sistem ilişkili bir mekanizmanın, AAA'in patogenezinde rol oynadığı düşünülmektedir. ${ }^{[9,30]}$ Olgularımızda deri döküntüsü olmadığından cilt biyopsisi yapılmamıştır. Ayrıca, son zamanlardaki çalışmalarda streptococcus gibi bazı enfeksiyöz ajanların, UFMS'unun bir tetikleyicisi olabileceğini vurgulamaktadırlar. ${ }^{[9,26]}$ Olgularımızın hiçbirinde başvuruda aktif streptokokal farenjit yoktu. Hastalarımızın ikisine ASO titresine bakılmış olup normal düzeylerde tespit edildi. Bu teori çok net değildir. Bu ilişkiyi açıklamak için daha fazla çalışmalara ihtiyaç vardır.

Elektromiyelografik inceleme ve kas biyopsisilerinde spesifik bulgusu yoktur ve bu tetkikler normal olarak saptanmaktadır. ${ }^{[18]}$ Serum kas enzim düzeyleri normaldir. ${ }^{[23]}$ Hastalarımızın kas enzimleri normaldi. Kas biyopsisi ve elektromiyografi yapılmadı. Ayrıca magnetik rezonans görüntülemede non spesifik subkutan yağ dokusunda ödem görülebilmektedir. ${ }^{[32]}$

Tedavi edilmeyen UFMS'lu hastalarda ateş yüksekliği 4-6 hafta kadar devam edebildiği bilinmektedir. Günümüzde UFMS benzeri klinik tablolarda ilk aşamada non steroidal antienflamatuar ilaçlar kullanılsa da genelde hastalar fayda görmemekte ya da istenilen yanıt alınamamaktadır. Semptomlarda gerileme olsa da bir süre sonra semptomların yeniden şiddetli şekilde ortaya çıktığı görülmektedir. Nitekim dört hasta bize başvurmadan önce non-steroid antiinflamatuar ilaçlar almış olup herhangi bir fayda görmemişti. AAA tanısı olan ve düzenli kolşisin tedavisi kullanan hastalarda da UFMS görüldüğü için kolşisinin UFMS tedavisinde yararı olmadığı düşünülmektedir. Ayrıca bazı çalışmalarda düşük doz oral steroid, interlökin (IL)1 reseptör antagonisti ve opiyatlar kullanılmıştır. ${ }^{[32]}$ Bu nedenle UFMS tedavisinde ilk tercih steroid tedavisidir. ${ }^{[31]}$ Tedavide ilk aşamada 3 gün kadar pulse steroid (10-30 mg/kg/gün metilprednizolon) verilmeli sonrasında idame steroid tedavisi sağlanmalıdır. Dikkat edilmesi gerek önemli bir nokta hastalığın şiddetine göre verilecek idame steroid tedavisinin azaltılarak 4-6 hafta kadar devam edilmesidir. Steroid tedavisinin erken kesilmesi myaljinin tekrar ortaya çıkışına neden olabilmektedir. Biz son bir yılda başvuran ve UFMS tanısı koyduğumuz hastalarımıza pulse steroid tedavisi verdik ve semptomların dramatik şekilde düzeldiğini gördük. Taburculuk sonrası hastalara en az 4 hafta süreyle idame steroid tedavisine devam edildi. Kontrole gelen hastalarımızda herhangi bir şikayeti yoktu ve takip süresinde de olmadı.

\section{Sonuç}

Günümüzde AAA farkındalığı artış göstermekte ancak atipik AAA vakalarının sayısı da artmaktadır. AAA kriterlerini karşıla- mayan, yüksek ateşle birlikte akut faz reaktanı yüksekliğinin olduğu ve uzun süren myalji varlığında UFMS düşünülmelidir. UFMS tedavisine erken zamanda steroid ile başlanılarak uygun doz ve sürede verilmelidir.

Finansal destek: Yazarlar bu çalışma için finansal destek almadığını belirtmiştir.

Çıkar çatışması: Bildirilmemiştir.

\section{Kaynaklar}

1. Ben-Chetrit $E$, Levy M. Familial Mediterranean fever. Lancet 1998;351:659-64.

2. Livneh A, Langevitz P, Zemer D, Zaks N, Kees S, Lidar T, et al. Criteria for the diagnosis of familial Mediterranean fever. Arthritis Rheum 1997;40:1879-85.

3. Sohar E, Gafni J, Pras M, Heller H. Familial Mediterranean fever. A survey of 470 cases and review of the literature. Am J Med 1967;43:227-53.

4. Eliakim M, Levy M, Ehrenfeld M. Recurrent polyserositis. Amsterdam: Elsevier/North-Holland Biomedical Press; 1981. p. 15.

5. Yilmaz E, Ozen S, Balci B, Duzova A, Topaloglu R, Besbas N, et al. Mutation frequency of Familial Mediterranean fever and evidence for a high carrier rate in the Turkish population. Eur J Hum Genet 2001;9:553-5.

6. Dinc A, Pay S, Turan M, Simsek I. Prevalence of familial Mediterranean fever in young Turkish men. Clin Exp Rheumatol 2000;18:292.

7. Majeed HA, Al-Qudah AK, Qubain H, Shahin HM. The clinical patterns of myalgia in children with familial Mediterranean fever. Semin Arthritis Rheum 2000;30:138-43.

8. Touitou I. The spectrum of familial Mediterranean fever (FMF) mutations. Eur J Hum Genet 2001;9:473-83.

9. Tekin M, Yalçinkaya F, Tümer N, Akar N, Misirlioğlu M, Cakar N. Clinical, laboratory and molecular characteristics of children with familial Mediterranean fever-associated vasculitis. Acta Paediatr 2000;89:177-82.

10. Ozdogan H, Arisoy N, Kasapçapur O, Sever L, Calişkan S, Tuzuner $\mathrm{N}$, et al. Vasculitis in familial Mediterranean fever. J Rheumotol 1997;24:323-7.

11. Langevitz $P$, Zemer D, Livneh A, Shemer J, Pras M. Protracted febrile myalgia in patients with familial Mediterranean fever. J Rheumatol 1994;21:1708-9.

12. Kaplan E, Mukamel M, Barash J, Brik R, Padeh S, Berkun Y, et al. Protracted febrile myalgia in children and young adults with familial Mediterranean fever: analysis of 15 patients and suggested criteria for working diagnosis. Clin Exp Rheumatol 2007;25:114-7.

13. Mauldin J, Cameron HD, Jeanotte D, Solomon G, Jarvis JN. Chronic arthritis in children and adolescents in two Indian health service user populations. BMC Musculoskeletal Disorders 2004;5:30.

14. Davies K, Copeman A. The spectrum of paediatric and adolescent rheumatology. Best Pract Res Clin Rheumatol 2006;20:179-200.

15. Yalçinkaya F, Ozen S, Ozçakar ZB, Aktay N, Cakar N, Düzova A, et al. A new set of criteria for the diagnosis of familial Mediterranean fever in childhood. Rheumatology (Oxford) 2009;48:395-8. 
16. Odabas AR, Cetinkaya R, Selcuk Y, Bilen H. Familial Mediterranean fever. South Med 2002;95:1400-3.

17. Koşan C, Diagnostic aproach to familial mediterranean fever [Article in Turkish]. Atatürk Üniversitesi Tıp Dergisi 2003;35:1-6.

18. Öztürk C, Sütçüoğlu S, Özer E, Aşık Akan S. Familial Mediterranean fever presenting with protracted febrile myalgia: A case report [Article in Turkish]. Behcet Uz Cocuk Hast Derg 2013;3:63-6.

19. Peru H, Karagül C, Ertoy Karagöl HI, Elmacı AM. A Case Of Familial Mediterranean Fever Presenting With Protracted Febrile Myalgia Syndrome [Article in Turrkish]. Ankara Üniversitesi Tıp Fakültesi Mecmuası 2008;61:93-5.

20. Öztürk C, Halıcıoğlu O, Coker I, Gulez N, Sutçuoglu S, Karaca N, et al. Association of clinical and genetical features in FMF with focus on MEFV strip assay sensitivity in 452 children from western Anatolia, Turkey. Clin Rheumatol 2012;31:493-501.

21. Schwabe AD, Peters RS. Familial Mediterranean fever in Armenians. Analysis of 100 cases. Medicine 1974;53:453-62.

22. Majeed HA, Rawashdeh M, el-Shanti H, Qubain H, Khuri-Bulos $\mathrm{N}$, Shahin HM. Familial Mediterranean fever in children: the expanded clinical profile. Q J Med 1999;92:309-18.

23. Livneh A, Langevitz P. Diagnostic and treatment concerns in familial Mediterranean fever. Baillieres Best Pract Res Clin Rheumatol 2000;14:477-98

24. Odabas AR, Cetinkaya R, Selcuk Y, Kaya H. Severe and prolonged febrile myalgia in familial Mediterranean fever. Scand J Rheumatol 2000;29:394-5.
25. Ertekin V, Selimoğlu MA, Alp H, Yilmaz N. Familial Mediterranean fever protracted febrile myalgia in children: report of two cases. Rheumatol Int 2005;25:398-400.

26. Soylu A, Kasap B, Türkmen M, Salyam GS, Kavukcu S. Febrile Myalgia Syndrome in Familial Mediterranean Fever. J Clin Rheumatol 2006;12:93-6.

27. Majeed HA, El-Khateeb M, El-Shanti H, Rabaiha ZA, Tayeh M, Najib $D$. The spectrum of familial mediterranean fever gene mutations in Arabs: Report of a large series. Semin Artritis Rheum 2005;34:813-8.

28. Sidi G, Shinar Y, Livneh A, Langevitz P, Pras M, Pras E. Protracted febrile myalgia of familial Mediterranean fever. Mutation analysis and clinical correlations. Scand J Rheumatol 2000;29:174-6.

29. Zaks N, Shinar Y, Padeh S, Lidar M, Mor A, Tokov I, et al. Analysis of the three most common MEFV mutations in 412 patients with familial Mediterranean fever. Isr Med Assoc J 2003;5:585-8.

30. Schlesinger M, Kopolovic J, Viskoper RJ, Ron N. A case of familial Mediterranean fever with cutaneous vasculitis and immune complex nephritis: Light, electron, and immunofluorescent study of renal biopsy. Am J Clin Pathol 1983;80:511-4.

31. Duru S, Civilibal M, Karakoyun M, Payasli M, Elevli M. Protracted febrile myalgia in two children with familial Mediterranean fever. Pediatr Int 2010;52:137-40.

32. Rom E, Amarilyo G, Levinski Y, Bilavsky E, Goldberg O, Amir J, et al. Protracted febrile myalgia syndrome treated with pulse of corticosteroids. Semin Arthritis Rheum 2018;47:897-9. 